\title{
Child Criminal Justice Reconstruction System (As the efforts of Children's Rights in conflict with the Press Law According to Legal Aid)
}

\author{
Adi Mansar \\ Lecturer in Faculty of Law, University of Muhammadiyah Sumatera Utara, Medan, Indonesia \\ Email: adimansar@umsu.ac.id
}

\begin{abstract}
:
Third Amendment to Article 1 Paragraph (3) confirms that "The State of Indonesia is a State of Law". Indonesia the rule of law originating from Pancasila and 1945 Constitution as stipulated in the People's Consultative Assembly of the Republic of Indonesia Number III / MPR / 2000 Concerning Legal Sources and Order of Laws and Regulations. The basic rights stipulated in the constitution have then been regulated in several legislative regulations, for example Law Number 11 Year 2012 concerning the Juvenile Justice System in Consideration letter a reads "that the child is the trust and gift of God Almighty who has dignity and dignity as complete be a human". The letter $b$ stated that "in order to maintain their dignity and status, children are entitled to special protection, especially legal protection in the justice system. Problem Formulation of How the Legal Arrangement of the Criminal Justice System for Children in Indonesia, How to Legal Instruments for the Protection of Children in Criminal Law. Fulfillment of the Rights of Children in conflict with the law should have been guaranteed since the child began to be determined as a suspect until the child began to carry out punishment/ guidance in Special Child Development Institute. .Recommendation of our Criminal System which is oriented towards coaching according to the purpose of punishment (objective theory) wherever possible provides education to children so that it is truly changing and aware. The Criminal Justice System for Children needs to be reconstructed specifically regarding the pattern of providing legal assistance, financing and special space for children in each prison, remand center in Indonesia. Child protection legal instruments in criminal law need to be updated, especially law enforcement with a miserable approach for children, so restorative justice needs to be grounded.
\end{abstract}

Keywords:

child criminal justice; children's right; special child development institute

\section{Introduction}

The 1945 Constitution of the Republic of Indonesia (UUDNRI) as a result of the third amendment to Article 1 Paragraph (3) confirms that "The State of Indonesia is a State of Law". Indonesian state law originates from Pancasila and the 1945 Constitution as stipulated in the People's Consultative Assembly of the Republic of Indonesia Number III/ MPR/ 2000 Concerning Legal Sources and Order of Laws and Regulations. The rule of law is a country that guarantees the basic rights of its citizens in the constitution from birth to death. In the life of a state there are many violations of the law by citizens who are adults or children or by the term children in conflict with the law.

Children who are in conflict with the law need to be a more serious concern, because children who are in conflict with the law cannot be compared to an adult's approach. Article 28D paragraph (1) reads "everyone has the right to recognition, guarantees, protection and certainty of law that is just and equal treatment before the law". The Constitution has guaranteed that every person is not treated discriminatively and violates human rights (Human Rights), in accordance with Article 28 I paragraph (2) reads "everyone 
has the right to be free from discriminatory treatment on any basis and has the right to get protection against treatment which is discriminatory ".

Pancasila is as a view of life and the basic governance of Indonesian society has become a philosophy with the aim of ensuring the survival and personality of the nation, so it must be in accordance with Pancasila. Basic rights of citizens are regulated in the constitution, so that every citizen has the right to receive legal protection and protection of human rights, as well as minors.

The basic rights stipulated in the constitution have then been regulated in several legislative regulations, for example Law Number 11 Year 2012 concerning the Juvenile Justice System in Consideration letter a reads "that the child is the trust and gift of God Almighty who has dignity and dignity as complete as human". The letter b reads "that in order to maintain their dignity and status, children are entitled to special protection, especially legal protection in the justice system".

The state upholds human rights as mandated by the constitution, including child rights which are marked by guarantees of protection and fulfillment of children's rights, in addition to the normative constitution the legal protection of children especially criminal law has been specifically regulated in accordance with Law Number 11 Year 2012 About the Juvenile Criminal System. This is in accordance with the purpose of protecting children as an effort of human survival and the survival of a nation and state, because children are the next generation of the nation which must be protected and guaranteed their welfare.

\section{Review of Literature}

Law Number 11 Year 2012 concerning the Juvenile Justice System mentions the terminology of Children, Child victims, Child witnesses. The child in question is a child in conflict with the law. Children in conflict with the law are children who are suspected of being criminals. What if a child is suspected of having committed a criminal offense and is processed by the Police and Prosecutors Office, the child is still a "suspect" and what if the court has examined it after the diversion stage fails to change its status to become "a defendant". Article 23 paragraph (1) of the SPPA Law reads "In every examination, children must be given legal assistance and be accompanied by a social supervisor or other companion in accordance with the provisions of the legislation".

The explanation of this article is quite clear, but normatively it is not certain how to provide legal assistance for children who are in conflict with the law if the parents / guardians of children do not know their children are in conflict with the law, what else if the child does not have parents anymore. The need for parents / guardians of children is to provide power of attorney or the like for legal aid providers for children who are in conflict with the law. Children are legally said to have not been competent, have not been able to make an agreement with another party so there must be a guardian, as well as the process of granting a special power of attorney for the legal aid provider. Children who are in conflict with the law must obtain legal assistance, the word mandatory according to this article means that if there is no legal assistance, then it is null and void and if the child or parent / guardian is unable to present an advocate as a legal aid provider, then it is free (prodeo). The state must present it. Legal protection for children who are in conflict with the law in the juvenile criminal justice process is to provide special protection for the child being examined who is being investigated for a crime committed in an emergency situation, the specific protection in question is 
imposing a criminal without weighting. Other protections in the form of having to pay attention to the best interests of the child and keep the family atmosphere maintained. Children in conflict with the law must keep their identities confidential from print and electronic media publications. Children who commit criminal acts before the age of 18 (eighteen) years and submitted to the trial after the age of 21 (twenty one) years, then the trial still uses the legal mechanism of the juvenile justice system. What a different case if there is a criminal offense by a child who is not yet 12 (twelve) years old, then the investigator, social counselor, and professional social worker make the decision to:

a) give back to parents / guardians; or

b) include it in education, coaching and mentoring programs in government agencies or LKPS in agencies that deal with social welfare, both at the central and regional levels for a maximum of 6 (six) months.

The child victim or witness child at any level of examination must be accompanied by parents and / or persons trusted by the victim's child and / or witness's child, or social worker. Assistance for children and child victims / witnesses has different mandatory characteristics, because if a child who is in conflict with the law must be accompanied by legal aid providers at all levels, but for child victims / witnesses children are not required to be accompanied by legal aid providers (advocates).

Law Number 11 Year 2012 concerning the Juvenile Criminal Justice System regulates the rights of children who are in conflict with the law, as Article 3 reads:

a. Humanly necessary by taking into account the needs according to their age;

b. Separated from adults;

c. Obtain legal assistance and other assistance effectively;

d. Conducting recreational activities;

e. Free from torture, punishment or other cruel, inhumane, and degrading treatment and dignity;

f. Not sentenced to death sentence or life imprisonment;

g. Not be arrested, detained or imprisoned, except as a last resort and in the shortest amount of time;

h. Obtain justice before the court of children that is objective, impartial, and in a closed hearing to the public;

i. Unpublished identity;

j. Obtaining the assistance of parents / guardians and people trusted by the child;

k. Obtaining Social Advocacy;

1. Getting a private life;

m. Obtain accessibility, especially for children with disabilities;

n. Get education;

o. Obtaining health services; and

p. Obtain other rights in accordance with statutory provisions.

If examined the purpose of "needs according to age" includes conducting worship in accordance with their religion or beliefs, getting visits from family and / or companions, getting physical and spiritual care, getting education and teaching, getting proper health and food services, getting reading material, filed complaints, and participated in mass media broadcasts. What is meant by recreation is daily free physical training activities in the open air and children must have extra time to attend daily entertainment, arts, or develop skills. What is meant by degrading the degree and dignity is that children are told to take off clothes and run around, children are shaved by their hair, children are handcuffed, children are told to clean 
toilets, and girls are told to massage male investigators. What is meant by undergoing a juvenile justice process is the right to enjoy personal life, for example a child is allowed to bring his personal equipment items, such as toys, and if the child is detained or placed in LPKA, the child has the right to have or carry a blanket or pillow, his own clothes, and given a bed separate. The exercise of the rights and obligations of children who commit a crime must receive assistance and protection to be balanced and humane. To put legal aid as a legal institution in juvenile justice has been separated from adult justice since the birth of Law no. 3 of 1997 concerning Juvenile Courts, so since the birth of Law No. 11 of 2012, protection of children in the judicial process is mandatory one of them with legal assistance. Thus it is necessary to pay attention and fight for the existence of children's rights, in the form of:

a. Every child is treated as an innocent person;

b. When juvenile justice is not interspersed with adult justice;

c. Every child has the right to be defended by an expert;

d. The atmosphere of question and answer is carried out as a family, so that children feel safe and not afraid.

e. The language used is the language understood by children;

f. Every child has the right to protection from harmful actions, causing mental, physical and social suffering;

g. Every child has the right to ask for compensation for his suffering (Article 1 point 22 of the Criminal Procedure Code).

h. Child trials may not be published in the mass media;

i. During the case investigation process, all officials or parties involved are not allowed to wear uniforms.

\section{Discussion}

Children who are in conflict with the law we hear more and more often brought to trial, because diversion is not successful, even though the criminal acts that occur in the form of petty crimes, such as theft. Some cases of children in conflict with the law do not get legal protection such as legal assistance, community workers and the presence of parents / guardians. In addition to children who are in conflict with the law must receive legal protection, child victims of crime and children as witnesses must also receive protection, in the form of:

a. The child as a victim has the right to an explanation of the crimes committed against the child;

b. To be entitled to protection from actions that threaten, persecute, and exploit which can cause material and immaterial losses;

c. Entitled to request compensation for suffering suffered by children;

d. Right to be tried in a closed trial;

e. Entitled to be accompanied by an advocate;

f. Eligible to get court facilities.

Children as witnesses are also given rights, in the form of:

a. The right to get facilities to attend the trial (transportation, escort, and security protection);

b. The right to get an explanation of the trial procedures;

c. The right to security protection;

d. The right to get permission from educational and development institutions that are places for learning. 
Protection of children's rights through legislation relating to the juvenile justice process there are several types, including:

3.1 National instruments based on the law, as follows:

a. Law Number 11 of 2012 concerning the Criminal Justice System for Children;

b. Law Number 1 of 1946 concerning the Criminal Code;

c. Law No. 6/1974 concerning Principal Social Welfare;

d. Law Number 4 of 1979 concerning Child Welfare;

e. Law Number 8 of 1981 concerning the Criminal Procedure Code;

f. Law Number 23 of 1992 concerning Health;

g. Law Number 12 of 1995 concerning Penitentiaries;

h. Law Number 3 of 1997 concerning Juvenile Courts;

i. Law Number 31 of 1999 concerning Eradication of Corruption;

j. Law Number 39 of 1999 concerning Human Rights;

k. Law Number 35 of 2014 concerning Child Protection changes to Law Number 23 of 2002 concerning Child Protection;

1. Law Number 1 of 1974 concerning Marriage;

m. Law Number 20 of 1999 concerning Ratification of ILO Conventions;

n. Law Number 25 of 1997 as amended and supplemented by Law Number 13 of 2003 concerning Manpower;

o. Law Number 35 of 2009 concerning Narcotics;

p. Law Number 5 of 1997 concerning Psychotropics;

q. Law Number 21 of 2007 concerning Eradication of Trafficking in Persons;

r. Law 23 of 2004 concerning Domestic Violence;

s. Law Number 7 of 1984 concerning the Elimination of All Forms of Discrimination Against Women;

t. Law Number 11 Year 2008 concerning ITE;

3.2 National Instruments based on Government Regulations and Decrees, as follows:

a. Presidential Instruction Number 6 of 1971;

b. Government Regulation Number 27 of 1983 concerning the Implementation of the Criminal Procedure Code;

c. Presidential Decree Number 36 of 1990 concerning Ratification of the Conventions on the Rights of the Child;

There are a number of regulations issued after the Presidential Instruction and Government Regulations issued by the Minister of Social Affairs and the Minister of Justice, but technically the judiciary that is used as the basis in the process of examining children's cases is in the form of SEMA and then the decision of the Indonesian Constitutional Court.

\subsection{Instruments of Decision of the Constitutional Court and Supreme Court}

a. PUU No.1 / PUU-VIII / 2010;

b. SEMA Number 6 of 1987 concerning the Standing Orders of the Children's Session;

Pancasila State has properly regulated the protection of children in the juvenile justice process, this is in accordance with the teachings and orders contained in Qur'an and Sunnah of the Prophet Muhammad SAW which indirectly became the philosophy of protecting children. 


\subsection{Based on Islamic Law}
a. Al-Qur'an Surah Al Maidah verse 8 and verse 48.
b. Al-Qur'an Surah An Nisa 'verse 6;
c. Al-Qur'an Surah Al An'aam verse 52;
d. Al-Qur'an Su rah As Surah verse 38.
e. Al-Qur'an Surah An Nisa 'verse 58 and verse 135.
f. Al-Qur'an Surah An Nahl verse 90.
g. Sunnah Rasul SAW Bukhori and Muslim narrations and Ahmad narrations, and Abu Dawud and Tarmizi.

As a source of fair law of the Qur'an and Sunnah, it turns out that customary law has already existed based on Islamic law specifically for the protection of children.

\subsection{Customary Law Instruments.}

Aminah Azis said that protecting children from criminal proceedings according to customary law refers to Ter Haar's opinion on the definition of adulthood according to customary law. In general, in North Tapanuli there is the term adult or non-child again as follows "the state of stopping as a child who is dependent on parents is the end of the period of immature, no longer when married".

\subsection{International Instruments.}

The Preamble to the Children's Rights Convention of 20 November 1989 states that children for the full development and harmony of their personalities must grow in a family environment in a climate of happiness, love and understanding.

Article 37 letter d reads:

"Every child deprived of liberty will have the right to immediately obtain legal assistance and other appropriate assistance, and have the right to oppose the legitimacy of deprivation of liberty before a court or other ruling authority, free and impartial, and entitled to a ruling fast regarding these actions ".

Nandang Sambas_legal protection for children can be interpreted as efforts to protect the law against various freedoms and human rights as well as various interests relating to the welfare of children. In addition to the Convention on the Rights of the Child there are several international instrument regulations which mention and protect children's rights, including:

a. 1924 Geneva Declaration of the Rights of the Child

b. 1959 UN General Assembly Declaration on the Rights of the Child

c. 1966 International Covenant on Civil and Rights of the Child

d. 1966 International Covenant on Economic, Social \& Cultural Rights

e. 1989 UN Convention on the Rights of the Child.

The above instrument has implemented a set of children's rights and obligations States that sign and ratify to protect children in the case of child labor, child adoption, armed conflicts, juvenile justice, child refugees, exploitation, health, family education, civil rights, and economic, social and political and cultural rights. Children in conflict with the law are specifically regulated through international instruments on juvenile justice standards, including:

1. Resolution No.40/33, 1985 (The Beijing Rules) Minimum UN Standard Rules Regarding the Administration of Justice for Children.

2. General Assembly Resolution No. 34/169 December 17, 1979 concerning Rules of Conduct for Law Enforcement Officials. 
3. Resolution No. 663 C (XXIV) dated July 31, 1957, and Resolution No. 2076 (LXII) dated May 13, 1977, concerning the Rules of the Minimum Standards for the treatment of prisoners.

4. Resolution No. 45/113, 1990 concerning UN Regulations for the protection of children who have lost their freedom.

5. The United Nations Minimum Standards on the Administration of Justice for Children (The Beijing Rules) Resolution No. 40/33 of 1985;

Nandang Sambas states that international instruments for the protection of children's rights other than the Universal Declaration of Human Rights (Universal Declaration of Human Rights) based on resolution No. 217 A (III) December 10, 1948, including:

1. International Convention on Civil and Political Rights (International Covenant on Civil and Political Rights), General Assembly Resolution 2200 A (XXI) dated 16 December 1966.

2. The Convention against Torture and other cruel, inhuman or degrading treatment or punishment (Convention against Torture and Other Cruel, Inbuman or Degrading Treatment or Punishment) Resolution 39/46 dated December 10, 1984.

3. Convention on the Rights of the Child (Convention on the Rights of the Child) resolution No. 109 of 1990.

4. Collection of Principles for the protection of all persons under any form of detention or imprisonment (Resolution 43/173 of December 9, 1988).

5. UNB Guidelines in the framework of the Prevention of Youth Crimes in 1990 (United Nations Guidelines for the Preventive of Juvenile Delinguency, "Riaydh Guidelines" resolution No. 45/112, 1990.

The legal basis for juvenile justice and child protection in the juvenile criminal justice process above becomes a reference in providing legal defense and assistance for children in conflict with the law, child victims, witness children at every level of the examination process, both investigation, prosecution, trial in court and the process of conducting legal remedies including diversion in the context of restorative justice.

\subsection{Reconstruction of the SPPA Law}

Juridical reconstruction is very appropriate for Law Number 11 of 2012 concerning the criminal justice system when analyzed with progressive legal theory, because the law is for humans, if there are unclear legal rules governing citizens' rights which are the State's obligation to guarantee it, then according to Satjipto Rahardjo, it is appropriate to make changes or improvements, because the law gives great attention to the role of human behavior in law. According to the authors of Law Number 11 Year 2012 still need to be made changes to the article governing legal aid, so that it is clearer and more accurate.

\section{Conclusion}

What if compared to the Australian State legal assistance for children in conflict with the law is the State's obligation to guarantee its availability, both in terms of costs, advocates and legal protection for children. Victoria legal aid, one of the legal aid institutions in Australia that has won the trust of the community in terms of legal assistance for children in conflict with the law, because the program is clearly regulated in one division, namely legal assistance for children and adolescents. Legal assistance for children in conflict with law in Indonesia does not expressly regulate the State's obligations in guaranteeing the provision of fees and advocates who have been appointed to provide legal assistance for children in conflict with the law when compared to South Africa which has placed legal assistance for suspects or 
compulsory criminal defendants given legal assistance, especially cases of children and adolescents.

Article 23 reads:

1. At each level of examination, children must be given legal assistance and be accompanied by a Community Guidance or other companion in accordance with the provisions of the legislation.

2. At each level of examination, the Victim Child or Witness Child must be accompanied by a parent and / or person trusted by the Victim Child and / or Witness Child, or Social Worker.

3. In the case of parents as suspects or defendants in the case being examined, the provisions referred to in paragraph (2) do not apply to parents.

This article does not provide guarantees for children in conflict with the law to obtain legal assistance free of charge and automatically and it is the State's obligation to guarantee both the costs and the advocates who provide legal assistance. Article 23 paragraph (1) of Law No. 11 of 2012 needs to be reconstructed to reflect justice, humanity, and civilization, because:

1. The state does not explicitly appoint advocates to provide legal assistance for children in conflict with the law.

2. The state has not automatically guaranteed the availability of free legal aid costs for children in conflict with the law.

3. The State has not confirmed in the form of the State's obligation to provide legal assistance as a form of legal protection for children in accordance with the law.

4. Children who are in conflict with the law should be accompanied by a Community Advisor or other companion.

\section{References}

Dwija Priyatno, Sistem Pelaksanaan Pidana Penjara di Indonesia, Refika Aditama, Bandung, 2006

P.A.F Lamintang, Hukum Penitensier Indonesia, Sinar Grafika, Jakarta, 2010

C.I Harsono Hs, Sistem Baru Pembinaan Narapidana, Djambatan, Jakarta, 1995

Imam Muhammad Syirazi, Islam Melindungi Hak-hak Tahanan, Zahra, jakarta, 2004.

Abintoro Prakoso, Pembaharuan Sistem Peradilan Pidana Anak, Edisi Revisi, Aswara, Yogyakarta, 2016.

Elsam, Hak-hak Narapidana, ELSAM, Jakarta, 1996.

Adi Mansar dan Ikhwaluddin Simatupang, Hukum Acara Pidana Indonesia dalam Persfektif Advokat dan Bantuan Hukum, Jabal Rahmah, Medan, 2007

Barda Nawawi Arief, Kebijakan Hukum Pidana (Perkembangan Penyusunan Konsep KUHP Baru), Kencana Prenadamedia Group, 2014 Kebijakan Legislatif Dalam Penanggulangan Kejahatan Dengan Pidana Penjara, Badan Penerbit Universitas Diponegoro, Semarang, 1996. Kapita Selekta Hukum Pidana, Citra Aditya Bakti, Bandung, 2010

Dedi Mulyadi, Internalisasi Nilai-Nilai Ideologi Pancasila (Dalam Dinamika Demokrasi dan Perkembangan Ketatanegaraan Indonesia), PT. Refika Aditama, Bandung, 2014

Derita Prapti Rahayu, Budaya Hukum Pancasila, Thafa Media, Yogyakarta, 2014

Didi Kusnadi, Bantuan Hukum Dalam Islam (Profesi Kepengacaraan Dalam Islam dan Prakteknya di Lingkungan Pengadilan), CV. Pustaka Setia, Bandung, 2012 